\title{
The Effects of Resistance and Aerobic Exercises on Adiponectin, Insulin Resistance, Lipid Profile and Body Composition in Adolescent Boys with Obesity
}

\author{
Obezitesi Olan Adolesan Erkeklerde Direnç ve Aerobik Egzersizlerin Adiponektin, \\ İnsülin Direnci, Lipid Profili ve Vücut Kompozisyonu Üzerine Etkileri
}

\author{
(D) Meral Küçük Yetgin1, (D) Ani Agopyan¹, (D) Ferit Kerim Küçükler2, (1) Asuman Gedikbașı³, (1) Soner Yetgin4, \\ (1) Fatma Çelik Kayapınar5 ${ }^{5}$, (1) Nurper Özbar6, (1) Bilal Biçer7, (1) Hasan Birol Çotuk
}

\begin{abstract}
${ }^{1}$ Marmara University Faculty of Sport Sciences, Department of Coaching Education, İstanbul, Turkey
2istanbul Atașehir Memorial Hospital, Clinic of Endocrinology, İstanbul, Turkey

3 istanbul University Institute of Child Health, Department of Pediatric Basic Sciences, İstanbul, Turkey

${ }^{4}$ TEV Ezel Gülen Kıray Vocational and Technical Anatolian High School, İstanbul, Turkey

5 Izmir Democracy University Faculty of Health Sciences, Department of Sport Sciences, Izmir, Turkey

${ }^{6}$ Düzce University Faculty of Sport Sciences, Department of Coaching Education, Düzce, Turkey

${ }^{7}$ Hatay University Faculty of Physical Education and Sports, Hatay, Turkey
\end{abstract}

\begin{abstract}
Introduction: This present study aimed to examine the effects of long-term resistance exercise (REG) and aerobic exercise (AEG) on the adiponectin, insulin resistance, lipid profile and body composition in adolescent boys with obesity.

Methods: Sixteen obese adolescent boys (age: $16.81 \pm 0.91$ years) who studied at high school in İstanbul voluntarily participated in the study. The participants were randomly divided into two groups of (REG; $n=8$ ) and (AEG; $n=8$ ). The participants followed their exercise schedule for six months (3 days/wk, $60 \mathrm{~min} /$ day). The serum lipid profile, adiponectin, glucose, insulin resistance (HOMA-IR) levels and body composition of the participants were evaluated at the beginning and end of the study. A Wilcoxon matched-pairs signed-rank test and Mann-Whitney $\mathrm{U}$ test were used for analyses, and the criterion for statistical significance was set at $p<0.05$.

Results: HOMA-IR, insulin, glucose and serum lipid levels decreased in both groups $(p<0.05)$. Adiponectin and highdensity lipoprotein increased only in the AEG $(p<0.05)$. Lowdensity lipoprotein level was statistically decreased only in the REG $(p<0.05)$.

Conclusion: These results indicated that both types of exercises had positive effects on insulin resistance, per cent body fat, weight and fat-free body mass. Long-term (6 months) aerobic and REG had different positive effects on adiponectin and the lipid profile. Although the effects of long-term aerobic exercise on biochemical parameters are higher than REG, it was remarkable that REG proved to be an alternative model to AEG. Keywords: Adiponectin, insulin, lipid profile, exercise, obesity
\end{abstract}

\section{ÖZ}

Amaç: Bu çalışma obezitesi olan erkek adolesanlarda, uzun süreli direnç egzersizin (DEG) ve aerobik egzersizin (AEG), adiponektin, insülin direnci, lipid profili ve vücut kompozisyonu üzerindeki etkilerinin incelenmesi amacıyla yapılmıştır.

Yöntemler: Çalışmaya, İstanbul ilindeki liselerde öğrenim gören 16 obez erkek adolesan (yaş: 16,81 $\pm 0,91$ yıl) gönüllü katılmıştır. Katılımcılar, (DEG; $n=8$ ) ve (AEG; $n=8$ ) egzersiz grupları olmak üzere ikiye ayrılarak, altı ay boyunca (3 gün/hafta, 60 dakika/gün) egzersiz programlarını takip etmiștir. Çalıșmanın bașlangıcında ve sonunda gönüllülerin vücut kompozisyonları ölçülmüş; ayrıca alınan kan örneklerinden, serum lipid profili, adiponektin, glikoz, insülin direnci (HOMA-IR) düzeyleri ve vücut kompozisyonu değerlendirilmiștir. Analizler için Wilcoxon eșlenik-çift testi ve Mann-Whitney U testi kullanıldı ve istatistiksel anlamlılık kriteri $p<0,05$ olarak belirlenmiștir.

Bulgular: Her iki grupta da HOMA-IR, insülin, glikoz ve vücut yağ düzeyleri azaldı $(p<0,05)$. Adiponektin ve yüksek yoğunluklu lipoprotein artışının sadece AEG'de olduğu gözlenmiştir ( $p$ $<0,05)$. Düşük yoğunluklu lipoprotein düzeyi sadece DEG'de istatistiksel olarak azaldığı belirlenmiștir $(p<0,05)$.

Sonuç: Bu sonuçlar, her iki egzersiz türünün de insülin direnci, vücut ağırlığı ağırlık ve yağsız vücut kütlesi ve vücut yağ yüzdesi üzerinde olumlu etkileri olduğunu göstermiștir. Uzun süreli (6 ay) aerobik ve DEG'nin adiponektin ve lipid profili üzerinde farklı pozitif etkileri vardır. Uzun süreli AEG'nin biyokimyasal parametreler üzerindeki etkileri, DEG'den daha fazla olmasına rağmen, DEG'nin AEG'ye alternatif bir model olduğu dikkat çekmektedir.

Anahtar Kelimeler: Adiponektin, insülin, lipid profili, egzersiz, obezite
Address for Correspondence/Yazıșma Adresi: Meral Küçük Yetgin Assoc. Prof., Marmara University Faculty of Sport Sciences, Department of Coaching Education, İstanbul, Turkey

Phone: +90 5303048742 E-mail: meral.kucukyetgin@marmara.edu.tr ORCID ID: orcid.org/0000-0002-4916-5661

Cite this article as/Atıf: Küçük Yetgin M, Agopyan A, Küçükler FK, Gedikbașı A, Yetgin S, Çelik Kayapınar F, Özbar N, Biçer B, Çotuk HB. The Effects of Resistance and Aerobic Exercises on Adiponectin, Insulin Resistance, Lipid Profile and Body Composition in Adolescent Boys with Obesity. İstanbul Med J 2020; 21(3): 182-9.

(C) Copyright 2020 by the University of Health Sciences Turkey, Istanbul Training and Research Hospital/Istanbul Medical Journal published by Galenos Publishing House

(C) Telif Hakkı 2020 Să̆lık Bilimleri Üniversitesi istanbul Ĕgitim ve Araștırma Hastanesi/Istanbul Tıp Dergisi, Galenos Yayınevi tarafından basılmıștır.
Received/Geliș Tarihi: 20.12 .2019 Accepted/Kabul Tarihi: 15.04 .2020 


\section{Introduction}

The prevalence of being overweight and obesity in children, adolescents and adults have risen substantially worldwide (1). The European Union Action Plan on Childhood Obesity 2014-2020 emphasises physical activity as well as a regulated diet in children to halt this increase in the number of overweight and obese adolescents by 2020 (2).

Adipokines secreted from adipose tissue may play a key role in the pathogenesis of obesity, insulin resistance and atherosclerosis by increasing subclinical inflammation (3). Adiponectin is one of the main adipokines secreted from adipose tissue. Adiponectin facilitates the clearing of glucose, triglycerides and free fatty acids from plasma; it decreases gluconeogenesis and increases insulin sensitivity (4). Individuals with obesity have lower adiponectin but higher leptin levels than individuals without obesity (5). Leptin is a hormone released by adipose tissue that aids in the regulation of body weight and energy homeostasis. Increased fat mass causes an elevation in leptin levels, which signal satiety and a mild increase in the basal energy expenditure. On the other hand, decreasing the body's fat stores via regular exercise and/or dieting causes a reduction in leptin levels. However, exercise can also cause changes in leptin concentration without an accompanying change in body composition.

Different forms of exercise training could favourably modify weightrelated complications, cardiovascular risk factors and the inflammation (6). Recently, resistance exercise has been recommended for children with obesity. While aerobic exercise is primarily an aerobic energyproducing process, resistance exercise is a type of exercise that increases primarily the force generation capacity of muscles (7). No consensus exists about the probable role of exercise in children on reductions in body fat and its effect on adipokines (e.g. adiponectin) (8). Only a few studies have investigated the effects of resistance exercise on adipokines, lipids and insulin resistance in adolescents $(9,10)$.

Information about health-related factors and early intervention effects among adolescents with obesity are important aspects in establishing targeted strategies and promoting lifestyle changes for preventing diseases. A better understanding of the metabolic responses to different types of exercise may help tailor interventions to maximise the likelihood of achieving health benefits among adolescents with obesity. Within this context, the main purpose of this study was to compare the effects of structured six-month resistance versus aerobic-exercise programmes on the serum lipid profile, adiponectin and insulin resistance.

\section{Methods}

\section{Participants}

For the recruitment of voluntary participants, we contacted state high schools near the selected fitness centre in the Sisli district of Istanbul. From this group, adolescents with obesity were selected according to Cole et al. (11) (who used "international cut-off points for Body Mass index (BMI)" for obesity by sex between 2 and 18 years old) and invited them to the initial meeting. Twenty-three students and their parents decided to participate in the 6-month study and provided informed consent. Seven of the participants dropped out of the study because of various reasons (non-compliance with the exercise schedule, Ramadan (fasting period) discontinuation), and the study was completed with 16 participants. This study was approved by the ethics committee of Marmara University Faculty of Medicine (116/27.02.2009). The study was performed, followed by the ethical guidelines of the Declaration of Helsinki. Before data collection, all participants provided written informed consent. Since all participants were younger than 18 years old, parents also gave written permission for participation.

Participants were excluded from this study if they had secondary obesity due to endocrine causes (Cushing's syndrome, hypothyroidism, others), used drugs for chronic diseases (diabetes mellitus, thyroid disease, cardiovascular disease, other conditions), were not able to exercise for any reason, or took part in a regular exercise programme in the last six months (except in physical education courses at school), or were smoking or drinking alcohol. The participants did not have any sports experience before the study. An experienced physician reviewed their complete medical history, performed a physical examination and assessed pubertal development according to the Tanner criteria. The Tanner stage was determined on a paper chart by the bariatric paediatrician during the physical examination of the participants (12). The Tanner scale defines stages based on the development of pubic hair and testicular volume in males. All participants were in Tanner stage IV-V.

The investigation was performed as a parallel-group design and lasted for six months. The participants were randomly divided into two exercise groups, the resistance-exercise group (REG) $(n=8)$ and the aerobicexercise group (AEG) $(n=8)$.

A dietitian provided the participants and their families with counselling and recommendations on balanced nutrition and considered the participant's age, gender and physical activity. However, a structured diet programme was not implemented throughout the study. The participants were asked not to consume any antioxidant supplements throughout the study.

\section{Experimental Protocol}

This study was conducted using two groups in a pre-post design interventional study without a control group at the Marmara University Athletic Health Research Center, İstanbul, Turkey. The duration of the study was six months. All participants visited the research unit three times, and they were familiarised with all experimental tests before the baseline performance. The tests were completed in three days in the same standardised environmental conditions. The same three dayprotocol was employed within the first week following the end of the 6-month exercise programme.

The participants were requested not to perform strenuous exercise in the last 24 hours before testing. They were instructed to avoid drinking or eating for at least 12 hours before the anthropometric measurements, and blood samples were taken. In addition, exercise test participants were advised to abstain from caffeine and taurine products, such as coffee and energy drinks, for 24 hours before the test. Questionnaires were completed to determine age, obesity history, possible chronic disease history, dietary habits and problems that they might encounter during their daily life activities using face-to-face interviews. 


\section{Blood Sampling and Analysis of Biochemical Markers}

Blood samples were obtained at the same time of day (8.00 Am to 9.30 AM) following a 12-hour overnight fasting period; a venous blood sample was taken in separate dry-gelled tubes twice to measure the initial values before and after the exercise period. The tubes were centrifuged at 2000 $\mathrm{g}(10 \mathrm{~min})$ to remove the serum. The blood samples were analysed within an hour for routine clinical, biochemical tests. Serum glucose, total cholesterol, triglyceride and high-density lipoprotein (HDL) and low-density lipoprotein (LDL) cholesterol levels were colourimetrically measured by Abbott Aeroset Clinical Chemistry Autoanalyzer using commercial kits (Abbott Aeroset, Abbott Diagnostics, Abbott Park, IL, USA). Serum-free T4 and thyroid stimulating hormone levels were measured by Abbott Architect automated chemiluminescence immunoassay with commercial kits (Abbott Diagnostics, Abbott Park, IL, USA). Insulin levels were determined by Immulite 1000 chemiluminescence autoanalyser and used commercial kits (Siemens, USA). Serum levels of adiponectin were assessed by the enzyme-linked immunosorbent assay (ELISA) technique. Adiponectin levels were measured with AssayMax Human Adiponectin (Acrp30) ELISA Kit (catalogue EA2500-1, Lot 7250521) by the ELISA method based on the sandwich method (Assaypro, Missouri, USA). The homeostatic model assessment for insulin resistance (HOMA-IR) method was used to determine insulin resistance.

\section{Anthropometric Measurements}

Body composition (height, weight, body fat weight and percentage, abdominal fat, lean body mass, body muscle mass) was determined with a body composition analyser (X-SCAN, Jawon Medical, Korea). Measurements were performed while the participants were wearing light clothing and no shoes. The BMI was calculated as weight $(\mathrm{kg}) /$ height $^{2}\left(\mathrm{~m}^{2}\right)$. BMI cut points for overweight and obesity are based on recently developed international BMI values for adolescents (11).

\section{Exercise Programmes}

Both groups attended their specialised exercise programme for six months for three sessions per week (3 days/wk, $60 \mathrm{~min} /$ day) at the same time of each day (4.00 PM-5.00 PM) and the same days of the week (Monday, Wednesday and Friday) throughout the intervention period (from February - August). The intensity of exercise was controlled by a Polar telemetric pulse metre (Polar 5625x, Polar Electro Oy, Finland) attached to the participant's chest.

Each exercise session was divided into warm-up (10 minutes), main exercise (45 minutes) and cool-down (5 minutes) sections. The standard warm-up (walking, jogging, multidirectional movements, dynamic stretching exercises of large muscle groups) and cool-down exercises (mild stretching, slow-paced walking, breathing exercises, relaxation) were performed before and after the main exercise section. The main exercise sections were structured separately for the two groups. Every exercise session of the exercise programmes was supervised by two advisers who were in the research group.

\section{Aerobic-exercise Programmes}

The exercise prescription consisted of 6 months of progressive cardiovascular exercise at a local fitness centre. The exercise intensity was designed for intensity of the maximum heart rate of $50 \%-60 \%$ for the first two months, $60 \%-70 \%$ for the third and fourth months and $70 \%$ $75 \%$ for the fifth and sixth months.

The exercise intensity was determined using the Karvonen method (13). The AEG participants performed aerobic exercises on treadmills and elliptical devices and some general strength exercises with different versions (sit-ups, back extensions, squats, push-ups) using only their body weight. A 30-second rest between movements with 3 minutes between sets was provided. The aerobic protocol required one to three sets, 10-20 repetitions of four to six exercises per session.

\section{Resistance-exercise Programme}

The exercise prescription consisted of 6 months of progressive resistance exercise at a local fitness centre. From the baseline assessment of maximum strength, the initial one-repetition maximum (1-RM) of the individual participants of REG was estimated. The fitness equipment weights that participants were able to move were determined by attempting to lift different weights. This procedure to evaluate maximal muscle strength has also proved to be relatively safe for children and adolescents (14). The resistance-exercise sessions consisted of total body workouts comprising a combination of different body weight and power exercises using a variety of equipment. Accordingly, the appropriate exercise programme for each individual was established by calculating $50 \%-60 \%$ of $1-$ RM during the first two months, $60 \%-70 \%$ of 1 -RM during the second two months and $70 \%-75 \%$ of $1-$ RM during the last two months. The initial 1RM measures were used to calculate exercise weights. The first workout consisted of two sets of 15 repetitions during weeks 1-8 and three sets of 15 repetitions during weeks 9-24. Rest periods were provided for 60 seconds between movements and 2 minutes between sets. Exercises included chest pulls, leg extensions, leg curls, push-ups, reverse push-ups, chest presses, biceps, triceps and shoulder presses.

\section{Statistical Analysis}

Descriptive statistics were expressed as mean values, medians, SDs, first and third quartiles and value ranges. The normality of variables was tested by the Shapiro Wilks test. The nonparametric Wilcoxon signedrank test was used to determine within-group differences between the values of variables among time. The nonparametric Wilcoxon matched-paired signed-rank test was used to assess the significance of the differences between the mean values of variables in the groups. Differences between groups were computed using a nonparametric Mann-Whitney $U$ test. The criterion for statistical significance was set as $p<0.05$.

\section{Results}

The demographic and body composition variables of pre-test and post-tests for the participants are presented in Table 1. There was no statistically significant difference between the pretest $(p>0.05)$ results related to demographic, body composition (Table 1) and biochemical values (Table 2). All participants had obesity according to the international age-related cut-off points for childhood obesity. There was a significant difference $(p<0.05)$ for height between pre- and post-tests for both groups (Table 1). The BMI decreased $(p<0.05)$ between pre- and post-tests for the REG group. Body fat percentage decreased significantly 
$(p<0.05)$ after exercise in both groups (Table 1$)$ with weight, body fat and fat-free mass stability ( $p>0.05)$.

In the AEG, there were significant differences between pre- and post-test values for HDL, adiponectin, glucose, insulin and HOMA-IR (Table 2). The AEG also had a positive effect on triglyceride, LDL and total cholesterol; however, the result was not statistically significant. In the REG, there were significant differences between pre- and post-test values for LDL, glucose and HOMA-IR parameters (Table 2). Resistance exercise had a positive effect on triglycerides, HDL, total cholesterol and adiponectin and insulin, although a statistically significant difference was not found. There were no significant differences for pre- and post-test results between groups for any of the demographic, body composition (Table 1) and biochemical (Table 2) variables of interest.

\section{Discussion}

The present study was conducted to compare the effects of structured 6-month (3 days/wk, $60 \mathrm{~min} /$ day) resistance exercise versus aerobicexercise programmes on the serum lipid profile, adiponectin, insulin resistance and body composition. The main finding of this study was that HOMA-IR, insulin, glucose and body fat percentage significantly decreased in both exercise groups without losing weight. Adiponectin and HDL increased only in the AEG, and LDL decreased only in the REG. These results indicated that both types of exercises had positive effects on insulin resistance and per cent body fat with weight and fat-free mass stability. Long-term (6-months) aerobic and resistance exercises had different positive effects on adiponectin and lipid profiles. Although the effects of long-term aerobic exercise on biochemical parameters are higher than resistance exercise, resistance exercises could be proved as an alternative model to aerobic exercises.

Exercise leads to changes in glucose and lipid metabolism mediated by adipokines. However, the research findings regarding the effects of exercise on serum leptin, adiponectin, lipid and insulin levels in children with obesity and youth are not equivocal. Some studies reveal that adiponectin levels increase, and leptin levels decrease after aerobic exercises $(15,16)$. Conversely, other studies show no changes in adiponectin and leptin levels after aerobic exercises (17). While the decrease in total cholesterol and LDL levels were minimal, the increase in HDL levels was significantly high in most exercise-lipid studies (18). On the other hand, Sénéchal et al. (19) investigated metabolic

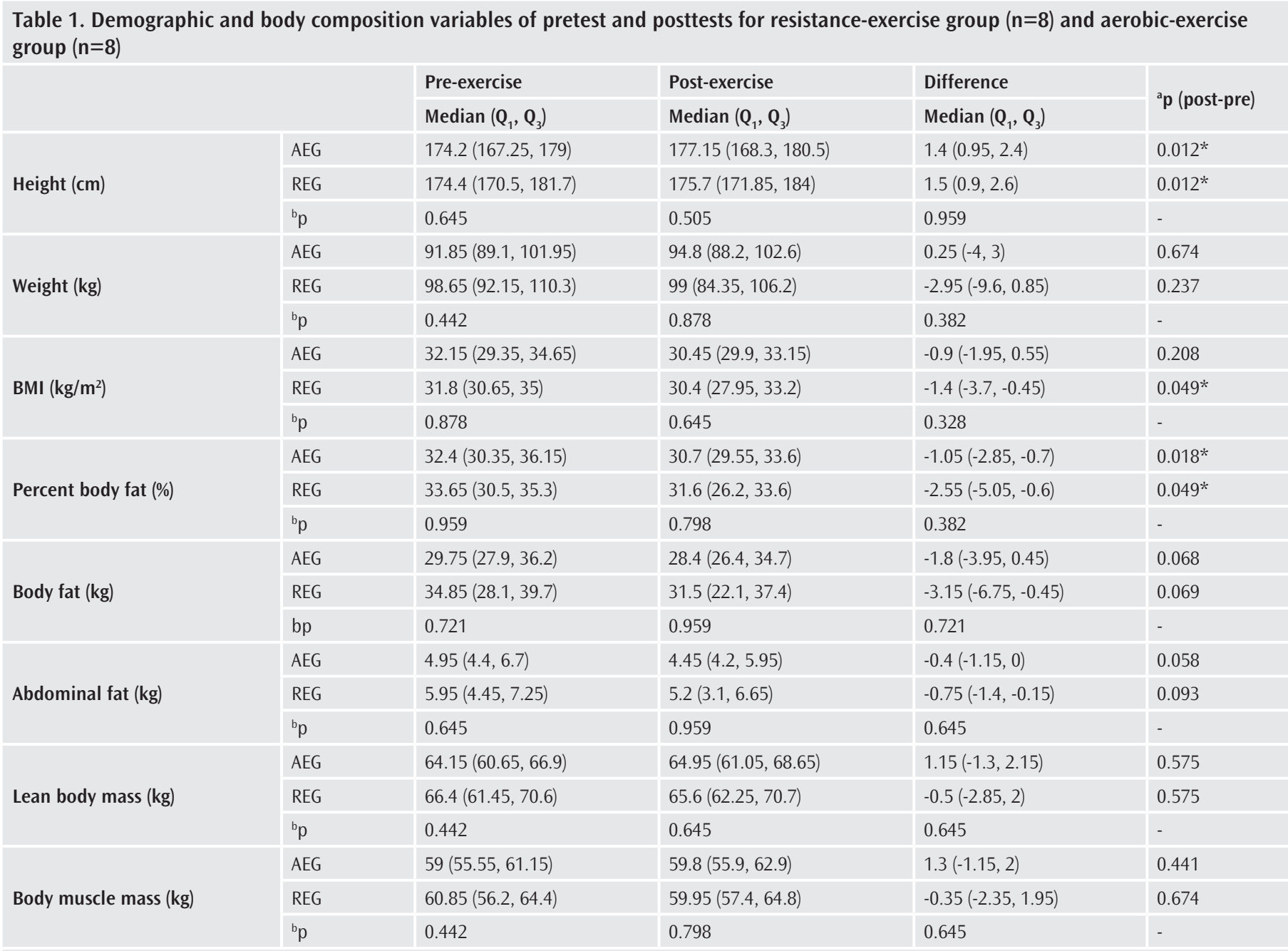

Notes: Data are presented as mean \pm SD, SD: standard deviation, ${ }^{a}$ : Wilcoxon signed-rank test, ${ }^{\mathrm{b}}:$ Mann-Whitney U test, ${ }^{*}: \mathrm{p}<0.05$, Data are presented as mean \pm SD, REG: resistanceexercise group, AEG: aerobic-exercise group, BMI: Body Mass index, $Q_{1}$ : first quartile, $Q_{3}$ : third quartile, $\mathrm{cm}$ : centimeter, kg: kilogram 
responses in overweight individuals and adolescents with obesity (1319 years old) following a 6-month (3 days/wk, 30-45 min/day) vigorousintensity aerobic exercise ( $>70 \%$ of heart rate reserve), a moderateintensity aerobic exercise (40\%-55\% of heart rate reserve), or a control group. They provided evidence that the metabolic response to aerobic exercise in overweight individuals and adolescents with obesity at risk of type 2 Diabetes Mellitus was significantly related to the increase in cardiorespiratory fitness.

Adiponectin is a novel adipose-specific collagen and plays a significant role in metabolic disorders (20). The review by Bouassida et al. (21) reported disparate findings on the responses of adiponectin to shortand long-term exercise in sedentary and trained subjects. In addition, there is a lack of consensus about the effects of exercise on adiponectin in children and adolescents. Regarding exercise modality, the systematic review reported that concurrent aerobic plus resistance exercise improves body composition, metabolic profiles and inflammatory state in the obese paediatric population (10). In the present study, the adiponectin level increased only in the AEG.

Contrary to our results, aerobic exercises did not affect the level of adiponectin in various studies in the paediatric population (22).
However, our findings agree with previous reports where aerobic exercise increased adiponectin levels (23). On the other hand, the results of the present study do not support previous reports where resistant exercise increased adiponectin levels. Montrezol et al. (24) have shown that resistance exercises increased adiponectin levels. Both aerobic and resistance exercise improved plasma adiponectin levels in about onethird of trials, including sedentary, overweight and subjects with obesity or type 2 diabetes (19). These different findings regarding adiponectin levels can be explained by the study design or the subject profiles. A systematic review of the literature showed that a relationship between exercise and increased adiponectin levels were not observed in the majority of randomised controlled trials to date. However, this does not indicate that exercise is ineffective in this regard. Rather, it highlights the necessity for more robustly designed studies (25). Besides, in light of the recent conclusion that concurrent exercise is recommended to modify body composition and reduce adiponectin levels, at this point, the available data is insufficient to conclude the adipokine response to different modes of exercise (26).

The response of the lipid profile was partially different in our two exercise groups. While the total cholesterol and triglyceride levels remained

Table 2. Biochemical test variables of pretest and posttests for resistance-exercise group $(n=8)$ and aerobic-exercise group ( $n=8$ )

\begin{tabular}{|c|c|c|c|c|c|}
\hline & & Pre-exercise & Post-exercise & Difference & an Inot nul \\
\hline & & Median $\left(\mathbf{Q}_{1}, \mathbf{Q}_{3}\right)$ & Median $\left(\mathbf{Q}_{1}, \mathbf{Q}_{3}\right)$ & Median $\left(\mathbf{Q}_{1}, \mathbf{Q}_{3}\right)$ & p (posepte) \\
\hline & $\mathrm{AEG}$ & $97.5(96.5,101.5)$ & $91(86.5,94.5)$ & $-9.5(-13,-4.5)$ & $0.017^{*}$ \\
\hline & ${ }^{b} p$ & 0.234 & 0.574 & 0.161 & - \\
\hline & AEG & $17.55(14,24.7)$ & $10.82(6.43,15.68)$ & $-7.88(-9.49,-4.78)$ & $0.017^{*}$ \\
\hline & AEG & $4.35(3.52,5.91)$ & $2.27(1.49,3.69)$ & $-2.16(-2.57,-1.6)$ & $0.017^{*}$ \\
\hline HOMA-IR & REG & $3.41(2.1,4.92)$ & $1.75(1.38,2.18)$ & $-1.46(-2.27,-0.32)$ & $0.012^{*}$ \\
\hline & ${ }^{b} p$ & 0.382 & 0.279 & 0.328 & - \\
\hline & AEG & $171.5(152,185.5)$ & $173(147.5,185.5)$ & $-4.5(-12,15)$ & 0.889 \\
\hline Triglyceride (mg/dL) & REG & $117(83,169)$ & $110(86,125)$ & $-14.5(-30,21)$ & 0.528 \\
\hline & ${ }^{b} p$ & 0.721 & 0.161 & 0.161 & \\
\hline & AEG & $110.7(95.3,118.3)$ & $107(77.4,118.9)$ & $-10.9(-8.1,2.7)$ & 0.141 \\
\hline $\mathrm{LDL}(\mathrm{mg} / \mathrm{dL})$ & REG & $80.8(77.2,113)$ & $72.5(63.2,99.5)$ & $-12.2(-15.7,-1.5)$ & $0.034^{*}$ \\
\hline & ${ }^{b} p$ & 0.195 & 0.130 & 0.798 & - \\
\hline & AEG & $34(31,37)$ & $39(33.5,42.5)$ & $4(1.5,6)$ & $0.027^{*}$ \\
\hline HDL $(m g / d L)$ & REG & $34(30.5,43.5)$ & $36(35,38.5)$ & $1.5(-1.5,3.5)$ & 0.473 \\
\hline & ${ }^{b} p$ & 0.798 & 0.442 & 0.195 & - \\
\hline & AEG & $5.86(5.05,14.35)$ & $9.58(7.27,13.73)$ & $2.58(0.74,3.72)$ & $0.036^{*}$ \\
\hline
\end{tabular}

Notes: Data are presented as mean \pm SD, SD: standard deviation, ${ }^{a}$ :Wilcoxon signed-rank test; ${ }^{\text {b }}$ : Mann-Whitney U test, *: p $<0.05$, REG: resistance-exercise group, AEG: aerobic-exercise group, HOMA-IR: insulin resistance, LDL: low-density lipoprotein, HDL: high-density lipoprotein, $Q_{1}$ : first quartile, $Q_{3}$ : Third quartile 
unchanged in both the AEG and REG, the HDL level increased only in the AEG, and the LDL level decreased only in the REG. Our findings are discordant with some, but not all, similar studies in children and adults. Previous studies demonstrated that the increase in HDL was found to be higher in the aerobic group in adults and children (27). Aerobic exercises should be preferred in risk groups because a high value for HDL is an important parameter concerning the prevention of cardiovascular diseases. Even though resistance exercise has a strong potential for clearing circulating cholesterol, in our study in the REG the decrease in total cholesterol did not reach statistical significance. Our findings are in agreement with previous reports that studied the effects of resistance exercise on the lipid profile in adolescents with obesity and reported no significant changes in concentrations of total cholesterol, triglyceride and HDL and LDL cholesterol levels (28-30). Although the participants were asked to maintain healthy eating habits, they had unrestricted living conditions. Therefore, we cannot exclude the potential bias induced by modified caloric intake, and, in particular, fat intake (31). Previous studies have reported the beneficial effects of exercise on insulin resistance in children and adolescents $(32,33)$. Improved insulin sensitivity and reduced abdominal fat accumulation have been reported in response to exercise with and without weight loss in children and adolescents (22). A 12-week aerobic-exercise programme and an 8-week combined aerobic and resistance-exercise programme without weight loss resulted in decreased insulin resistance in sedentary children and adolescents with obesity $(21,34)$. The findings of both these studies are in line with our results. In the present study, we observed that both resistance and aerobic exercises reduce HOMA-IR by decreasing the percentage of body fat. Our findings also provide preliminary evidence that aerobic and resistance-exercise models may also decrease insulin and glucose levels, although this outcome needs to be confirmed in a large cohort.

Body composition assessment is used to verify the health status of the population in general (35). BMI also provides a measure of obesity and is a predictor of overweight-related health risks and can be used when planning workplace intervention programmes (36). Although many studies looking at the effect of exercise on body composition have been published with obese adolescents, there is still no consensus in the field (26). Our results show that the reduction of BMI occurred in the REG but not in the AEG. These data indicate that BMI may be a poor indicator for the assessment of body composition and weight changes in children and adolescents (37). In the present study, we also showed that resistance or aerobic exercises without body weight loss or change in lean body mass resulted in a decreased percentage of body fat.

In contrast, Ackel-D'Elia et al. (1) showed that in adolescents with obesity aerobic plus resistance exercise (three times a week, one $\mathrm{h}$ per day, for six months), is effective in improving body composition, including a decrease in body fat and increase in lean body mass. It has been reported that in adolescents, the combination of aerobic and strength exercise resulted in the loss of more fat mass (38). Davis et al. (38) showed decreases in the absolute body fat mass in overweight Latin American adolescents subjected to nutritional therapy and a combination of aerobic and strength exercise. Tsiros et al. (39) emphasised that dietary interventions are more effective in achieving weight loss when combined with other strategies, such as increased physical activity levels and/or psychological interventions to promote behaviour changes. However, only aerobic combined strength exercise was sufficient for maintaining lean body mass. A variety of factors might have contributed to the conflicting data in different studies. Although energy restriction and a combination of aerobic and strength exercises were not investigated in our study, it can be concluded that these factors may also affect body composition.

\section{Study Limitations}

The present study has some limitations that should be considered. since we could not include a non-exercise control group and used a multidisciplinary intervention approach that involved nutritional and clinical counselling, it is difficult to delineate the independent effect of exercise in the current study. The small sample size of the participant group can be considered a further limitation of our study. Additional studies with larger sample sizes and a non-exercise control group are needed with changes in metabolic parameters, fitness levels and body composition induced by different exercise models and a hypocaloric diet. It is also important to keep in mind that our sample included only young boys; therefore, the results of this investigation should not be generalised to both genders.

\section{Conclusion}

The present study provides important practical applications for health and sport sciences. The results indicate that safe, effective and alternative-exercise modes can be useful in adolescents with obesity. Sixmonth (3 days/wk, $60 \mathrm{~min} /$ day) aerobic or resistance exercises without caloric restriction were effective in reducing body fat percentage-in adolescent boys with obesity. Furthermore, it was remarkable that resistance exercise proved to be an alternative to aerobic exercise, the effects of which on metabolic parameters (such as glucose, insulin, HOMA-IR, HDL and adiponectin) are well known. However, the positive effects of long-term aerobic exercise on biochemical parameters are higher than resistance exercise. The application of resistance and aerobic exercises in combination may have an additive effect on adipokines. The data presented here demonstrate important health implications for understanding the benefits of different exercise modalities to improve body composition and an additive effect on metabolic parameters in adolescents with obesity.

\section{Ethics}

Ethics Committee Approval: This study was approved by the ethics committee of Marmara University Faculty of Medicine (116/27.02.2009).

Informed Consent: Twenty-three students and their parents decided to participate in the 6-month study and provided informed consent.

Peer-review: Externally and internally peer-reviewed.

Authorship Contributions: Surgical and Medical Pracites - M.K.Y., A.A., A.G., H.B.Ç.; Concept - M.K.Y., A.A., F.K.K., S.Y.; Design - M.K.Y., A.A., H.B.Ç.; Data Collection and/or Processing - M.K.Y., F.K.K., S.Y., F.C..K., N.Ö.; Analysis and/or Interpretation - M.K.Y., A.A., F.K.K., A.G., S.Y., F.C..K., 
N.Ö., H.B.Ç.; Literature Search - M.K.Y., A.A., F.K.K., A.G., S.Y., F.C..K., N.Ö., H.B.Ç.; Writing - M.K.Y., A.A., F.K.K., H.B.Ç.

Conflict of Interest: No conflict of interest was declared by the authors.

Financial Disclosure: Financial support for this study was obtained from the Scientific Research Projects Commission Unit of Marmara University.

\section{References}

1. Ackel-D'Elia C, Carnier J, Bueno CR, Campos RMS, Sanches PL, Clemente APG, et al. Effects of different physical exercises on leptin concentration in obese adolescents. Int J Sports Med 2014; 35: 164-71.

2. European Union (EU) Action Plan on Childhood Obesity 2014-2020. 2014. Available at: http://www.ec.europa.eu/health/nutrition_physical_activity/ docs/childhoodobesity_actionplan_2014_2020_en.pdf [accessed 01.03.2017].

3. Dandona P, Aljada A, Bandyopadhyay A. Inflammation: the link between insulin resistance, obesity and diabetes. Trends Immunol 2004; 25: 4-7.

4. Kadowaki T, Yamauchi T, Kubota N, Hara K, Ueki K, Tobe K. Adiponectin and adiponectin receptors in insulin resistance, diabetes, and the metabolic syndrome. J Clin Invest 2006; 116: 1784-92.

5. Akbarpour M. The effect of aerobic training on serum adiponectin and leptin levels and inflammatory markers of coronary heart disease in obese men. Biol Sport 2013; 30: 21-7.

6. Parhampour B, Dadgoo M, Vasaghi-Gharamaleki B, Torkaman G, Ravanbod R, Mirzaii-Dizgah I, et al. The effects of six-week resistance, aerobic and combined exercises on the pro-inflammatory and anti-inflammatory markers in overweight patients with moderate haemophilia A: A randomized controlled trial. Haemophilia 2019; 25: e257-66.

7. Taylor NF, Dodd KJ, Damiano DL. Progressive resistance exercise in physical therapy: a summary of systematic reviews. Phys Ther 2005; 85: 1208-23.

8. Jamurtas AZ, Stavropoulos-Kalinoglou A, Koutsias S, Koutedakis Y, Fatouros I. Adiponectin, resistin, and visfatin in childhood obesity and exercise. Pediatr Exerc Sci 2015; 27: 454-62.

9. Faigenbaum AD. State of the art reviews: Resistance exercise for children and adolescents are there health outcomes? Am J Lifestyle Med 2007; 1: 190-200.

10. García-Hermoso A, Ramírez-Vélez R, Ramírez-Campillo R, Peterson MD, Martínez-Vizcaíno $V$. Concurrent aerobic plus resistance exercise versus aerobic exercise alone to improve health outcomes in paediatric obesity: a systematic review and meta-analysis. Br J Sports Med 2018; 52: 161-6.

11. Cole TJ, Bellizzi MC, Flegal KM, Dietz WH. Establishing a standard definition of child overweight and obesity worldwide: international survey. BMJ 2000; 320: 1240

12. Kapoor S. Diagnosis and treatment of acanthosis nigricans. Skinmed 2010; 8: 161-4.

13. Karvonen MJ, Kentala E, Mustala 0. The effects of exercise on heart rate: a longitudinal study. Ann Med Exper Fenn 1957; 35: 307-15.

14. Faigenbaum AD, Myer GD. Resistance exercise among young athletes: safety, efficacy and injury prevention effects. Br J Sports Med 2010; 44: 56-63.

15. Kim ES, Im JA, Kim KC, Park JH, Suh SH, Kang ES, et al. Improved insulin sensitivity and adiponectin level after exercise exercise in obese Korean youth. Obesity 2007; 15: 3023-30.

16. Racil G, Ounis OB, Hammouda O, Kallel A, Zouhal H, Chamari K, et al. Effects of high vs. moderate exercise intensity during interval exercise on lipids and adiponectin levels in obese young females. Eur J Appl Physiol 2013; 113: 2531-40.
17. Yokoyama H, Emoto M, Araki T, Fujiwara S, Motoyama K, Morioka T, et al. Effect of aerobic exercise on plasma adiponectin levels and insulin resistance in type 2 diabetes. Diabetes Care 2004; 27: 1756-8.

18. Kelley GA, Kelley K. Aerobic exercise and HDL 2-C: A meta-analysis of randomized controlled trials. Atherosclerosis 2006; 184: 207-15.

19. Sénéchal M, Rempel M, Duhamel TA, Macintosh AD, Hay J, Wicklow B, et al. Fitness is a determinant of the metabolic response to aerobic exercise in adolescents at risk of type 2 diabetes mellitus. Obesity 2015; 23: 823-32.

20. Yadav A, Kataria MA, Saini V, Yadav A. Role of leptin and adiponectin in insulin resistance. Cline Chim Acta 2013; 417: 80-4.

21. Bouassida A, Chamari K, Zaouali M, Feki Y, Zbidi A, Tabka Z. Review on leptin and adiponectin responses and adaptations to acute and chronic exercise. $\mathrm{Br}$ J Sports Med 2010; 44: 620-30.

22. Nassis GP, Papantakou K, Skenderi K, Triandafillopoulou M, Kavouras SA, Chrousos GP, et al. Aerobic exercise improves insulin sensitivity without changes in body weight, body fat, adiponectin, and inflammatory markers in overweight and obese girls. Metabolism 2005; 54: 1472-9.

23. Heijden GJ, Wang ZJ, Chu ZD, Saurer PJJ, Haymond MW, Rodriguez LM, et al. 12 week aerobic exercise program reduces hepatic fat accumulation and insulin resistance in obese, hispanic adolescents. Obesity 2010; 18: 384-90.

24. Montrezol F, Antunes H, Almeida V, Gomes RJ, Medeiros A. Resistance exercise promotes reduction in blood pressure and increase plasma adiponectin of hypertensive elderly patients. J Hypertens 2014; 3: 1-6.

25. Simpson KA. Singh MAF. Effects of exercise on adiponectin: a systematic review. Obesity 2008; 16: 241-56.

26. Sirico F, Bianco A, D’Alicandro G, Castaldo C, Montagnani S, Spera R, et al. Effects of physical exercise on adiponectin, leptin, and inflammatory markers in childhood obesity: systematic review and meta-analysis. Child Obes 2018; 14: 207-17.

27. Janssen I, LeBlanc AG. Systematic review of the health benefits of physical activity and fitness in school-aged children and youth. Int J Behalv Nutr Physical Act 2010; 7: 40.

28. Patel SJ, Hanks LJ, Ashraf AP, Gutierrez OM, Bamman MM, Casazza K. Effects of 8 week resistance exercise on lipid profile and insulin levels in overweight/ obese peri-pubertal boys-a pilot study. J Diab Res Clin Met 2015; 4: 1-8.

29. Lau PW, Yu CW, Lee A, Sung RY. The physiological and psychological effects of resistance exercise on Chinese obese adolescents. J Exerc Sci Fit 2004; 2 : $115-20$.

30. Watts K, Beye P, Siafarikas A, Davis EA, Jones TW, O'Driscoll G, et al. Exercise normalizes vascular dysfunction and improves central adiposity in obese adolescents. J Am Coll Cardiol 2004; 43: 1823-7.

31. Pereira MA, Weggemans RM, Jacobs DR, Hannan PJ, Zock PL, Ordovas JM, et al. Within-person variation in serum lipids: implications for clinical trials. Int J Epidemiol 2004; 33: 534-41.

32. Farpour-Lambert NJ, Aggoun Y, Marchand LM, Martin XE, Hermann FR, Beghetti M. Physical activity reduces systemic blood pressure and improves early markers of atherosclerosis in pre-pubertal obese children. J Am Coll Cardiol 2009; 54: 2396-406.

33. Mendelson M, Michallet AS, Monneret D, Perrin C, Esteve F, Lombard PR, et al. Impact of exercise without caloric restriction on inflammation, insulin resistance and visceral fat mass in obese adolescents. Pediatr Obes 2015; 10 : 311-9.

34. Bell LM, Watts K, Siafarikas A, Thompson A, Ratnam N, Bulsara M, et al. Exercise alone reduces insulin resistance in obese children independently of changes in body composition. J Clin Endocrinol Metab 2007; 92: 4230-5. 
35. Zaccagni L, Barbieri D, Gualdi-Russo E. Body composition and physical activity in Italian university students. J Transl Med 2014; 12: 120.

36. Huang JH, Huang SL, Li RH, Wang LH, Chen YL, Tang FC. Effects of nutrition and exercise health behaviors on predicted risk of cardiovascular disease among workers with different body mass index levels. Int J Environ Res Publ Health 2014; 11: 4664-75.

37. Ho M, Garnett SP, Baur LA, Stewart L, Neve M, Collins C. Impact of dietary and exercise interventions on weight change and metabolic outcomes in obese children and adolescents: a systematic review and meta-analysis of randomized trials. JAMA Pediatr 2013; 167: 759-68.

38. Davis JN, Tung AMY, Chak SS, Ventura EE, Byrd-Williams CE, Alexander KE, et al. Aerobic and strength exercise reduces adiposity in overweight Latina adolescents. Med Sci Sports Exer 2009; 41: 1494-503.

39. Tsiros MD, Sinn N, Coates AM, Howe PRC, Buckley JD. Treatment of adolescent overweight and obesity. Eur J Pediatr 2008;167: 9-16. 